JESTT Vol. 2 No. 8 Agustus 2015

\title{
PENGARUH PERTUMBUHAN DANA PIHAK KETIGA TERHADAP LABA PERBANKAN SYARIAH DI [NDONESIA 1 !
}

\author{
Lutfiyah Putri Nirwana \\ Mahasiswa Program Studi S1 Ekonomi Islam-Fakultas Ekonomi dan Bisnis-Universitas Airlangga \\ Email : putrilutfiyah@gmail.com \\ Dina Fitrisia Septiarini \\ Departemen Ekonomi Syariah-Fakultas Ekonomi dan Bisnis-Universitas Airlangga \\ Email : Dina.fitrisia@gmail.com
}

\begin{abstract}
:
This research was aimed to find out the partial asnd simultaneous effect of wadiah current account, wadi'ah savings, mudharabah saving, and mudharabah deposits to profits in Islamic Banking. This research used quantitative approach. Statistical tool used is the multiple regression time series. The population in this research was Islamic banking industry recorded in Indonesian bank. The sample used is the Islamic Banks and Islamic Business Unit which data summarized in statistical reports of Islamic banking. The research period is January 2009 - October 2014. The simultaneous test resulst were wadi'ah current account, wadi'ah savings, mudharabah saving, and mudharabah deposits simultaneously had significant effect on profits of Islamic banking. The partial test showed that wadi'ah savings has significant effect against Islamic banking profit whereas of wadi'ah current account, mudharabah saving, and mudharabah deposits has no significant effect to Islamic banking profit.
\end{abstract}

Keywords : Wadi'ah Current Account, Wadi'ah Savings, Mudharabah Saving, and mudharabah deposits, profit

\section{I.PENDAHULUAN}

\section{Latar Belakang}

Ekonomi Islam bertujuan mewujudkan tingkat pertumbuhan ekonomi jangka panjang dan memaksimalkan kesejahteraan manusia. Perkembangan masyarakat yang semakin sadar akan Islam sebagai agama yang mengatur kehidupan masyarakat secara komprehensif dan universal, berpengaruh juga pada sektor perbankan. Perbankan syariah mulai berkembang pesat diberbagai Negara.

Perkembangan perbankan syariah di Negara-Negara muslim berpengaruh terhadap perkembangan perbankan di Indonesia. Eksistensi Bank Syariah di
Indonesia secara formal telah dimulai sejak tahun 1992 dengan diberlakukannya UU No.7 tahun 1992 tentang Perbankan. Undang-undang tersebut memberi kebebasan kepada bank dalam menentukan imbalan yang akan diberikan kepada nasabah, baik berupa bunga ataupun bagi hasil. Berdasarkan Undang-Undang Perbankan No.7 tahun 1992 tersebut, maka berdirilah Bank Muamalat Indonesia sebagai bank syariah di Indonesia. Perkembangan bank syariah semakin pesat tatkala dikeluarkannya Undang-Undang Nomor 10 Tahun 1998 tentang perbankan, revisi dari UndangUndang Nomor 7 Tahun 1992 yang memungkinkan perbankan menjalani dual banking sistem atau bank konvensional

1] Jurnal ini merupakan bagian dari skripsi dari Lutfiyah Putri Nirwana, NIM : 041114009 , yang diuji pada tanggal 27 April 2015 
dapat mendirikan divisi syariah (Muhammad, 2004: 4-5).

Kehadiran Bank Syariah sebagai salah satu solusi alternative terhadap persoalan pertentangan antara bunga dan bank dengan riba. Riba atau bunga diharamkan karena riba bermakna ziyadah atau tambahan. Seperti yang dijelaskan pada Surat Al-Baqarah ayat 275

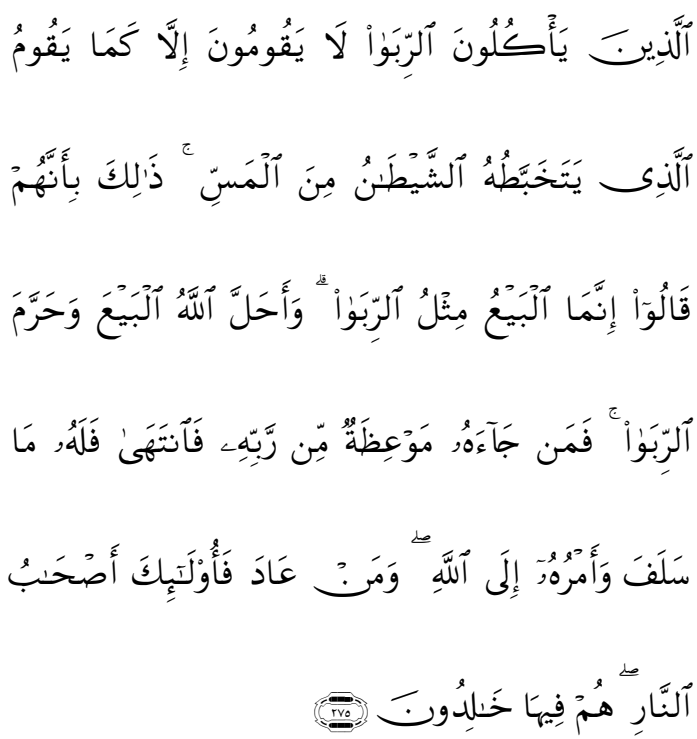

Alladżīnaya 'kulūnar-ribā laayaqūmūna illa kamā yaqūmul - lażī yatakhabbațuhusy-syaițānu minal massi żālika biannahum qālū innamāl bai'u miślur- ribā wa ahallallāhul bai'a wa harramar-ribā faman jāahū mau'izatum mirrabbihi fantahā falahūmā salafa wa amruhū ilallāhi wa man 'āda faulāika aşhābun- nāri hum fihā khalidūna

Artinya :"Orang-orang yang Makan (mengambil) riba tidak dapat berdiri melainkan seperti berdirinya orang yang kemasukan syaitan lantaran (tekanan) penyakit gila. Keadaan mereka yang demikian itu, adalah disebabkan mereka berkata (berpendapat), Sesungguhnya jual beli itu sama dengan riba, Padahal Allah telah menghalalkan jual beli dan mengharamkan riba. orang-orang yang telah sampai kepadanya larangan dari Tuhannya, lalu terus berhenti (dari mengambil riba), Maka baginya apa yang telah diambilnya dahulu (sebelum datang larangan); dan urusannya (terserah) kepada Allah. orang yang kembali (mengambil riba), Maka orang itu adalah penghuni-penghuni neraka; mereka kekal di dalamnya."( Q.S. 02 :275, Departemen Agama Rl, 2005 : 47) Perkembangan perbankan syariah di Indonesia menunjukkan adanya peningkatan. Perkembangan perbankan syariah selama satu tahun terakhir, sampai dengan bulan Oktober 2012 mampu tumbuh $\pm 37 \%$ sehingga total asetnya menjadi Rp174,09 triliun. Selama periode tahun 2012, jumlah Bank Umum Syariah (BUS) dan Unit Usaha Syariah (UUS) sampai dengan Oktober 2012 tidak mengalami perubahan, namun demikian jumlah jaringan kantor meningkat. (Bank Indonesia, Outlook Perbankan Syariah 2013 : 3).

Dana pihak ketiga (DPK) yang dihimpun BUS dan UUS sepanjang tahun 2013 tercatat tumbuh sebesar 24,4\%, sedangkan BPRS mencapai $24,8 \%$ dan melambat dibandingkan 
tahun 2012 yang mencapai 27,8\%, walaupun masih lebih tinggi dibandingkan pertumbuhan DPK perbankan nasional.Sumber dana perbankan syariah masih sangat didominasi oleh instrumen pendanaan jangka pendek sehingga mempengaruhi fleksibilitas bank dalam mengoptimalkan pengelolaan dana. Hal ini tercermin dari komposisi DPK BUS dan UUS yang sebagian besar terdiri atas instrumen giro dan tabungan yang sifatnya dapat ditarik sewaktu-waktu, serta deposito berjangka kurang atau sama dengan satu bulan, yang keseluruhannya memiliki porsi $82 \%$ dari total DPK.(Laporan Perkembangan Kevangan Syariah 2013, 2013 : 5 diakses di www.ojk.go.id)

Menurut Laporan Statistik Perbankan Syariah, Juni 2014, dari tahun ketahun komposisi dana pihak ketiga (DPK) yang terdiri dari Giro Wadiah, Tabungan Wadiah, Tabungan Mudharabah dan Deposito Mudharabahmengalami peningkatan. Diantara giro, tabungan, dan deposito yang memiliki jumlah terbanyak adalah deposito, kemudian tabungan dan diikuti giro. Dari sisi tabungan, yang paling banyak diminati masyarakat adalah tabungan dengan akad mudharabah. Sedangkan dari sisi deposito yang paling banyak diminati adalah deposito satu bulanan.
Salah satu indikator dari pertumbuhan bank syariah adalah aset yang dimiliki, dana pihak ketiga, pembiayaan. Penghimpunan DPK (Giro, Tabungan, dan Deposito) yang semakin mengalami peningkatan, mengindikasikan semakin besarnya perhatian dan kesadaran masyarakat dari berbagai golongan akan keberadaan lembaga kevangan (bank) yang sangat menguntungkan bagi mereka atas bagi hasil yang mereka peroleh begitu juga dengan laba yang diperoleh bank (Ekawati, $2010: 19)$.

Laba merupakan salah satu indikator penting dalam mengukur keberhasilan kinerja suatu perusahaan. Adanya pertumbuhan laba dalam suatu perusahaan dapat menunjukkan bahwa pihak-pihak manajemen telah berhasil dalam mengelola sumber-sumber daya yang dimiliki perusahaan secara efektif dan efisien. Secara bahasa laba bermakna pertumbuhan dalam dagang (Ibnu Mandzur,dalam Syahatah, 2001 :144).

\section{Rumusan Masalah}

$\begin{array}{rrr} & \text { Dari } & \text { uraian latar belakang } \\ \text { diatas } & \text { dapat dirumuskan }\end{array}$
permasalahan sebagai berikut :

1. Apakah Giro Wadi'ah berpengaruh terhadap laba perbankan syariah di Indonesia? 
2. Apakah Tabungan Wadi'ah berpengaruh terhadap laba perbankan syariah di Indonesia?

3. Apakah Tabungan Mudharabah berpengaruh terhadap laba perbankan syariah di Indonesia?

4. Apakah Deposito Mudharabah Mudharabah berpengaruh terhadap laba perbankan syariah di Indonesia?

5.Apakah Giro Wadi'ah,Tabungan Wadi'ah, Tabungan Mudharabah, dan Deposito Mudharabah berpengaruh secara simultan terhadap laba perbankan syariah di Indonesia?

\section{Tujuan Penelitian}

1. Untuk mengetahui pengaruh Giro Wadi'ah secara parsial terhadap laba pada perbankan syariah di Indonesia.

2. Untuk mengetahui pengaruh Tabungan Wadi'ah secara parsial terhadap laba pada perbankan syariah di Indonesia.

3. Untuk mengetahui pengaruh Tabungan Mudharabah secara parsial terhadap laba pada perbankan syariah di Indonesia.

4. Untuk mengetahui pengaruh Deposito Mudharabah secara parsial terhadap laba pada perbankan syariah di Indonesia

5. Untuk mengetahui pengaruh secara simultan Giro
Wadi'ah,Tabungan Wadi'ah,

Tabungan Mudharabah, dan Deposito Mudharabah terhadap laba pada perbankan syariah di Indonesia.

\section{II.TINJAUAN PUSTAKA}

\section{Definisi Bank}

Bank adalah lembaga perantara keuangan atau biasa disebut financial intermediary. Artinya lembaga bank adalah lembaga yang dalam aktivitasnya berkaitan dengan masalah vang. Oleh karena itu, usaha bank akan selalu dikaitkan dengan masalah vang yang merupakan alat pelancar terjadinya perdagangan yang utama. (Muhammad, 2000 : 63).

\section{Definisi Bank Syariah}

Bank Islam atau selanjutnya disebut dengan Bank Syariah menurut Muhammad (2000 :13) adalah bank yang beroperasi dengan tidak mengandalkan pada bunga. Bank Islam atau biasa disebut dengan Bank Tanpa Bunga, adalah lembaga keuangan/perbankan yang operasional dan produknya dikembangkan berlandaskan pada Al-Qur'an dan Hadits Nabi SAW.

\section{Prinsip Operasional Bank Syariah}

1. Prinsip Simpanan Murni (Al-Wadi'ah)

2. Bagi Hasil (Syirkah)

3. Prinsip Jual Beli (At-Tijarah)

4. Prinsip Sewa (Al-ljarah)

5. Prinsip fee/jasa (al-Ajr Wal Umulah) Muhammad (2005:175-177)

\section{Sumber Dana Bank Syariah}


Menurut Kuncoro dan Suharjono (2002:151) Dana Bank adalah semua utang dan modal yang tercatat pada neraca bank sisi pasiva yang dapat digunakan sebagai modal operasional bank dalam rangka kegiatan penyaluran/penempatan dana.

Ismail (2010:40) Sumber dana bank yang digunakan sebagai alat untuk melakukan aktivitas usaha dapat digolongkan menjadi tiga, yaitu:

1. Dana sendiri (Dana Pihak Pertama)

Dana sendiri disebut juga dengan dana modal atau dana pihak I menurut Ismail (2010:40) adalah merupakan dana yag dihimpun dari pihak para pemegang saham bank atau pemilik bank

2. Dana Pinjaman (Dana Pihak Kedua)

Pinjaman yang berasal dari bank lain biasa dikenal dengan pinjaman antarbank(Interbank Call Money).

3. Dana Pihak Ketiga

Dana pihak ketiga biasanya lebih dikenal dengan dana masyarakat, merupakan dana yang dihimpun oleh bank yang berasal dari masyarakat dalam arti luas, meliputi masyarakatindividu, maupun badan usaha. (Ismail, 2010:43

\section{Giro Wadi'ah}

Menurut UU RI No 10 tahun 1998 tentang Perubahan Atas UU No 7 Tahun 1992 Tentang Perbankan dalam Karim (2006 : 291), Giro adalah" simpanan yang penarikannya dapat dilakukan setiap saat dengan menggunakan cek, bilyet giro, sarana perintah bayar lainnya, atau dengan pemindahbukuan". Sedangkan yang dimaksud dengan giro syariah menurut Karim (2006:291), giro syariah adalah giro yang dijalankan berdasarkan prinsip-prinsip syariah.

Dalam kaitannya dengan produk giro, Bank Syariah menerapkan prinsip wadiah yad dhamanah, yakni nasabah bertindak sebagai penitip yang memberikan hak kepada Bank Syariah untuk menggunakan atau memanfaatkan vang atau barang titipannya, sedangkan Bank Syariah bertindak sebagai pihak yang dititipi yang disertai hak untuk mengelola dana titipan dengan tanpa mempunyai kewajiban memberikan bagi hasil dari keuntungan pengelolaan dana tersebut. Namun demikian, Bank Syariah diperkenankan memberikan insentif berupa bonus dengan catatan tidak disyaratkan sebelumnya. (Karim, 2006 :292)

\section{Tabungan Wadi'ah}

Berdasarkan UU No 10 tahun 1998 tentang Perubahan Atas UU No 7 Tahun 1992 tentang Perbankan dalam Karim (2006 : 297), yang dimaksud dengan tabungan adalah simpanan yang penarikannya hanya dapat dilakukan menurut syarat tertentu yang disepakati, tetapi tidak dapat ditarik dengan cek, bilyet giro, dan atau alat lainnya yang dipersamakan dengan 
itu. Adapun yang dimaksud dengan tabungan syariah menurut Karim (2010:345) adalah tabungan yang dijalankan berdasarkan prinsip-prinsip syariah.

\section{Tabungan Mudharabah}

Yang dimaksud dengan tabungan mudharabah menurut Karim (2010:347) adalah tabungan yang dijalankan berdasarkan akad mudharabah. Seperti yang telah dikemukakan pada bab-bab terdahulu, mudharabah mempunyai dua bentuk, yakni mudharabah mutlaqah dan mudharabah muqayyadah, yang perbedaan utama di antara keduanya terletak pada ada atau tidaknya persyaratan yang diberikan pemilik dana kepada bank dalam mengelola hartanya.

\section{Deposito Mudharabah}

Berdasarkan UU No 10 Tahun 1998 tentang Perubahan atas UU No 7 Tahun 1992 tentang Perbankan, yang dimaksud dengan deposito berjangka adalah simpanan yang penarikannya hanya dapat dilakukan pada waktuwaktu tertentu menurut perjanjian antara penyimpan dengan bank yang bersangkutan.

Adapun yang dimaksud
dengan deposito syariah menurut
Karim (2010:351) adalah deposito yang
dijalankan berdasarkan prinsip syariah.
Dalam hal ini, Bank Syariah bertindak
sebagai mudharib sedangkan nasabah
bertindak sebagai shahibul mal. Dalam

kapasitasnya sebagai mudharib, Bank Syariah dapat melakukan berbagai macam usaha yang tidak bertentangan dengan prinsip syariah serta mengembangkannya, termasuk melakukan akad mudharabah dengan pihak ketiga.(Karim, 2010:351)

\section{Hubungan Antar Variabel}

1. Dana yang dihimpun bank syariah dari masyarakat salah satunya berbentuk Giro (Muhammad, 2004 :42). Penghimpunan dana yang dilakukan oleh Bank Syariah untuk dapat disalurkan kepada masyarakat yang membutuhkan dana dengan harapan bank yang bersangkutan tetap mampu memenuhi kriteriakriteria likuiditas, rentabilitas dan solvabilitas.(Muhammad, 2004 :43).Hubungan antara Giro Wadiah terhadap laba telah dilakukan penelitian sebelumnya oleh Anto (2009), penelitian ini menjelaskan bahwa Giro Wadiah berpengaruh tidak signifikan terhadap profitabilitas Bank Syariah di Indonesia.

2. Dana pihak ketiga dapat berasal dari simpanan Tabungan Wadi'ah. Dana ini akan disalurkan dalam bentuk pembiayaan. Suatu kegiatan usaha (bisnis) yang dijalankan baik perusahaan maupun perbankan tentu memiliki beberapa tujuan yang ingin dicapai, yakni memperoleh laba yang optimal, disamping hal-hal lainnya (Kasmir, 2012:196).Hubungan antara Tabungan Wadiah terhadap 
laba telah dilakukan penelitian sebelumnya oleh Mahaputra (2008) menjelaskan bahwa Tabungan Wadi'ah secara bersama-sama dan parsial memiliki pengaruh yang positif terhadap variabel terikat yaitu laba bersih BPRS.

3. Bank Syariah dapat menghimpun dana dari masyarakat (dana pihak ketiga) dalam bentuk pastisipasi modal berbagi hasil dan berbagi resiko, dimana bank akan membayar bagian keuntungan secara proporsional yakni sesuai dengan nisbah bagi hasil, salah satunya berbentuk tabungan mudharabah. I Arifin, 2002 : 53). Untuk mengelola dana yang dihimpun maka diperlukan manajemen dana yang salah satunya bertujuan untuk memperoleh profit yang optimal. (Muhammad, 2004 :48). Hubungan antara Tabungan Mudharabah terhadap laba telah dilakukan penelitian sebelumnya oleh Nurdin (2005) yang menjelaskan bahwa tabungan mudharabah baik secara parsial maupun simultan mempengaruhi pembentukan laba.

4. Salah satu dari komposisi dana pihak ketiga adalah Deposito Mudharabah. Kasmir( 2012 : 65 dan 93) " simpanan deposito termasuk dana mahal karena dana yang dikeluarkan untuk membayar imbal jasa relatif mahal. Dana yang telah dikumpulkan bank salah satunya deposito mudharabah ini nantinya dialokasikan berdasarkan kebijakan yang telah digariskan, tujuannya agar bank dapat mencapai tingkat profitabilitas yang cukup dan tingkat resiko yang rendah. (Muhammad,2004:55). Hubung an antara Deposito Mudharabah terhadap laba telah dilakukan penelitian sebelumnya oleh Mahaputra (2008) yang menjelaskan bahwa Deposito Mudharabah secara bersama-sama dan parsial memiliki pengaruh yang positif terhadap variabel terikat yaitu laba bersih BPRS.

\section{Hipotesis}

Berdasarkan latar belakang, rumusan masalah, tujuan penelitian, landasan teori yang telah dikemukakan maka hipotesis dalam penelitian ini adalah :

Hipotesis 1:Giro Wadi'ah secara parsial berpengaruh signifikan terhadap laba perbankan syariah di Indonesia

Hipotesis 2: Tabungan Wadi'ah secara parsial berpengaruh signifikan terhadap laba perbankan syariah di Indonesia

Hipotesis 3:Tabungan Mudharabah secara parsial berpengaruh signifikan terhadap laba perbankan syariah di Indonesia

Hipotesis 4:Deposito Mudharabah secara parsialberpengaruh 
signifikan terhadap laba

perbankan syariah di

Indonesia

Hipotesis 5:Giro Wadi'ah, Tabungan

Wadi'ah, Tabungan

Mudharabah dan Deposito

Mudharabah secara

simultan berpengaruh signifikan

terhadaplaba perbankan syariah

di Indonesia.

\section{Model Analisis}

Model analisis dalam penelitian ini dapat digambarkan sebagai berikut :

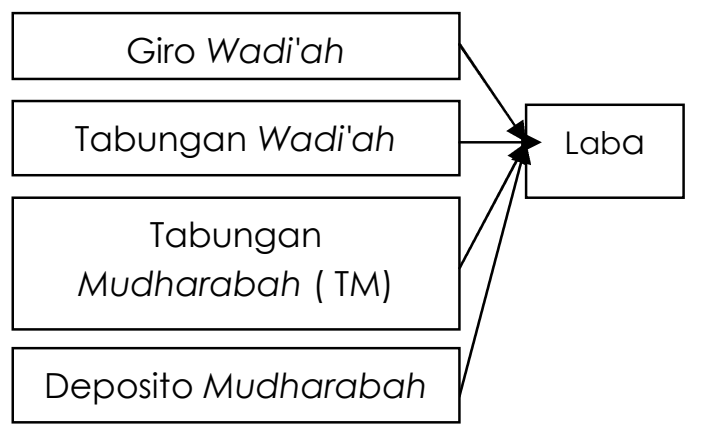

Sumber : Data diolah

Gambar 1.

Pengaruh Parsial Giro Wadi'ah, Tabungan Wadi'ah, Tabungan

Mudharabah dan Deposito

Mudharabah Terhadap Laba

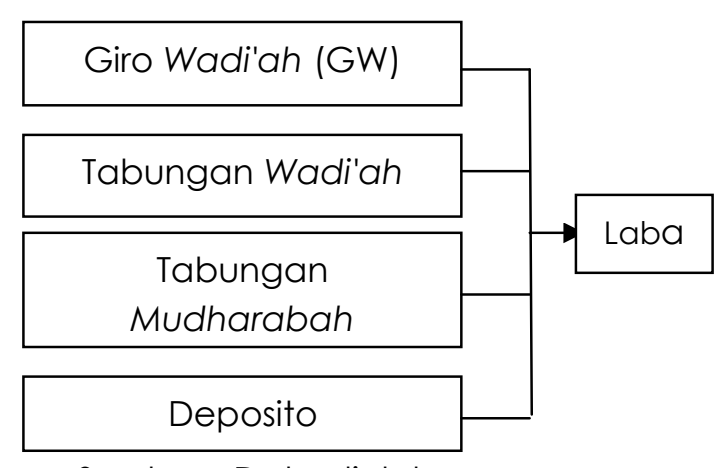

Sumber : Data diolah

Gambar 2.

Pengaruh Simultan Wadi'ah, Tabungan Wadi'ah, Tabungan
Mudharabah dan Deposito

\section{METODE PENELITIAN}

\section{Pendekatan Penelitian}

Pendekatan yang digunakan dalam peneltian ini adalah pendekatan kuantitatif. Penelitian kuantitatif merupakan penelitian terstruktur dan mengkualifikasikan data untuk dapat digeneralisasi (Anshori dan Iswati, 2009 :13). Teknik analisis yang digunkan untuk mengetahui hubungan antar variabel menggunakan regresi linier berganda. Adapun program statistik yang digunakan untuk mempermudah dalam pengolahan data menggunakan program SPSS versi 16,0 .

\section{Identifikasi Variabel}

Variabel yang digunakan dalam penelitian ini terdiri dari dua jenis, yakni variabel independen dan variabel dependen. Variabel independen adalah variabel bebas yang mempengaruhi variabel terikat/dependen. Adapun variabel independen dalam penelitian ini adalah giro wadiah, tabungan wadi'ah, tabungan mudharabah, deposito mudharabah. Variabel dependen adalah variabel terikat yang perubahannya dipengaruhi oleh variabel bebas/independen. Adapun dalam penelitian ini variabel dependen yang digunakan adalah laba perbankan Syariah di Indonesia.

\section{Definisi Operasional Variabel}


1. Giro Wadi'ah

Giro yang dijalankan berdasarkan prinsip syariah dan berdasarkan akad Wadi'ah.Nilai Giro Wadi'ah diperoleh dari Statistik Perbankan Syariah Bank Umum Syariah (BUS) dan Unit Usaha Syariah (UUS) bulanan mulai Januari 2009 hingga Oktober 2014 yang berbentuk data rasio yang dirumuskan dengan :

Pertumbuhan Giro Wadi'ah (GW) = $\mathrm{GW}_{+}-\mathrm{GW}_{\mathrm{t-l}} \times 100 \%$ $\mathrm{GW}_{\mathrm{t}-\mathrm{l}}$

\section{Tabungan Wadi'ah}

Tabungan yang dijalankan berdasarkan akad Wadi'ah. Nilai Tabungan Wadiah diperoleh dari Statistik Perbankan Syariah Bank Umum Syariah (BUS) dan Unit Usaha Syariah (UUS) bulanan mulai Januari 2009 hingga Oktober 2014 yang berbentuk data rasio yang dirumuskan dengan :

Pertumbuhan Tabungan Wadi'ah (TW) $=\frac{\mathrm{TW}_{+}-\mathrm{TW}_{\mathrm{t}-1}}{\mathrm{TW}_{\mathrm{t}-1}} \times 100 \%$

3. Tabungan Mudharabah

Tabungan yang dijalankan berdasarkanakad Mudharabah.

Nilai Tabungan Mudharabah diperoleh dari Statistik Perbankan Syariah Bank Umum Syariah (BUS) dan Unit Usaha Syariah (UUS) bulanan mulai Januari 2009 hingga Oktober 2014 yang berbentuk data rasio yang dirumuskan dengan :
Pertumbuhan

Tabungan

Mudharabah $(\mathrm{TM})=\underline{\mathrm{T} M_{+}-\mathrm{TM}_{\mathrm{t}-1}} \times 100 \%$

$\mathrm{TMt}-1$

4. Deposito Mudharabah

Deposito yang dijalankan berdasarkan akad Mudharabah. Nilai Deposito Mudharabah diperoleh dari Statistik Perbankan Syariah Bank Umum Syariah (BUS) dan Unit Usaha Syariah (UUS) bulanan mulai Januari 2009 hingga Oktober 2014 yang berbentuk data rasio yang dirumuskan dengan :

PertumbuhanDep.Mudharabah (DM)=

$\frac{\mathrm{DM}_{+}-\mathrm{DM}_{\mathrm{t}-1}}{\mathrm{DM}_{\mathrm{t}-1}} \times 100 \%$

5. Laba

Laba yang dimaksud peneliti dalam penelitian ini adalah laba bersih setelah pajak.. Nilai Laba diperoleh dari Statistik Perbankan Syariah Bank Umum Syariah (BUS) dan Unit Usaha Syariah (UUS) bulanan mulai bulan Januari 2009 hingga Oktober 2014 yang berbentuk data rasio yang dirumuskan dengan :Pertumbuhan Laba

$$
=\frac{\text { Labat }_{t} \text { Labat }-1_{\text {I }}}{\text { Labat }-1^{\prime}} \times 100 \%
$$

\section{Prosedur Pengumpulan Data}

Langkah-langkah yang dilakukan dalam prosedur pengumpulan data pada penelitian ini adalah sebagai berikut :

1. Survei pendahuluan bertujuan untuk mengetahui gambaran permasalahan yang diteliti dan menentukan faktor-faktor terkait yang 
dapat dipergunakan dalam penelitian.

2. Studi kepustakaan (library research), bertujuan untuk memperoleh informasi yang digunakan sebagai landasan teori dalam penelitian ini.

3. Pengumpulan data yang diperoleh dari publikasi umum statistik perbankan syariah dari periode 2009 2014 yang diterbitkan oleh Bank Indonesia. Semua data tersebut kemudian dikelompokkan dalam tabel-tabel dan diolah dengan menggunakan program SPSS versi 16,0 .

4.Penentuan populasi penelitian. Populasi dalam penelitian ini adalah industri perbankan syariah yang tercatat di Bank Indonesia.

5. Penentuan sampel. Sampel yang digunakan dalam penelitian ini adalah seluruh Bank Umum Syariah dan Unit Usaha Syariah yang didasarkan pada periode bulanan, yakni mulai Januari 2009 hingga Oktober 2014. Bank Pembiayaan Rakyat Syariah tidak disertakan dalam penelitian ini karena Bank Pembiayaan Rakyat Syariah tidak melakukan penghimpunan dana dalam bentuk giro, sedangkan penelitian ini menggunakan variabel giro. Periode penelitan yang digunakan adalah laporan dari bulan Januari 2009 sampai dengan oktober 2014

\section{Teknik Analisis Data}

Teknik analisis yang digunakan dalam penelitian ini adalah regresi linier berganda, sedangkan proses perhitungannya menggunakan program SPSS (Statistical Program for Social Science) versi 16. Tujuan analisis regresi berganda adalah menggunakan nilai-nilai variabel bebas yang diketahui untuk meramalkan nilai variabel tergantung.

\section{Uji Linearitas}

Pengujian linearitas bertujuan untuk mengetahui apakah data yang kita miliki sesuai dengan garis linier atau tidak (apakah hubungan antar variabel yang hendak dianalisis mengikuti garis kurus atau tidak). (Sarjono, dkk, 2011 :74. Untuk menguji apakah hubungan antar variabel linier atau tidak yaitu dengan menggunakan Uji LM (Lagrange Multiplier) yaitu dengan membandingkan nilai $c^{2}$ hitung dan nilai $c^{2}$ tabel. Apabila nilai $c^{2}$ hitung $<$ $c^{2}$ tabel maka hubungan tersebut adalah linier.

\section{Uji Asumsi Klasik}

Uji asumsi klasik terdiri dari uji normalitas, uji multikolinearitas, uji heteroskedastisitas, dan uji autokorelasi. Sedangkan uji regresi meliputi uji $F$ dan uji t.

Kegunaan Uji $F$ adalah untuk menentukan signifikansi atau tidak signifikansinya suatu variabel bebas secara bersama-sama dalam mempengaruhi variabel terikat. Uji $\dagger$ 
digunakan untuk mengetahui apakah variabel bebas yang dimasukkan dalam model secara parsial (sendirisendiri) memiliki pengaruh signifikan terhadap variabel terikat. Koefisien determinasi berganda $\left(R^{2}\right)$ berguna untuk mengukur besarnya sumbangan variabel independen secara keseluruhan terhadap variabek dependen (Sarjono, 2011:63).

\section{HASIL DAN PEMBAHASAN}

\section{Uji Linearitas}

Tabel 1.

Hasil Uji Linearitas Variabel Independen Terhadap Variabel Dependen

Model Summary

\begin{tabular}{|l|r|r|r|r|}
\hline $\begin{array}{l}\text { Mod } \\
\mathrm{el}\end{array}$ & $\mathrm{R}$ & $\mathrm{R}$ Square & $\begin{array}{c}\text { Adjusted R } \\
\text { Square }\end{array}$ & $\begin{array}{l}\text { Std. Error of } \\
\text { the Estimate }\end{array}$ \\
\hline 1 & $.300 \mathrm{a}$ & .090 & .034 & 41.67632545 \\
\hline
\end{tabular}

sumber: Data SPSS

Berdasarkan tabel 1 , nilai $R$ Square sebesar 0.090. Nilai $C^{2}$ Hitung

$=$ Nilai $\mathrm{R}^{2} \times \mathrm{N}=0,090 \times 70=6,3$.

$\mathrm{Df}=\mathrm{K}-1$, dimana $\mathrm{K}$ adalah jumlah variabel independen. Df $=\mathrm{K}-1=4-1=3$. Alfa yang digunakan $=5 \%$ atau 0,05 . Nilai $C^{2}$ Tabel dengan $D f=3$, dan alfa $=0,05$ adalah 7,815. Nilai $C^{2}$ Hitung $=6,3$ sedangkan nilai $\mathrm{C}^{2}$ tabel $=7,815$. Karena $\mathrm{C}^{2}$ hitung $<\mathrm{C}^{2}$ tabel, maka hubungan antar variabel dalam penelitian ini bersifat linear.

\section{Uji Normalitas}

Normalitas dapat diketahui dengan cara melihat grafik normal P-P Plot, apabila data menyebar disekitar garis diagonal dan mengikuti arah garis diagonal, maka model regresi memenuhi asumsi normalitas.Selain itu juga bisa menggunakan uji statistik non parametrik Kolmograv-Smirnov (K-S).

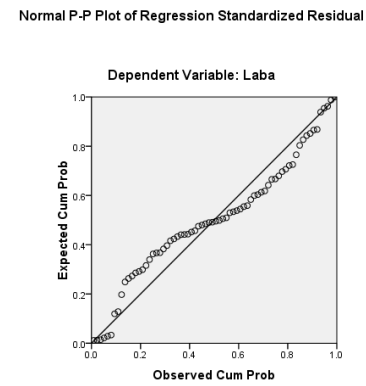

Sumber : Hasil Olah Data di SPSS

Gambar 3.

Grafik P-P Plot Hasil Uji

Tabel 2.

Tabel Kolmograv Hasil Uji Normalitas

One-Sample Kolmogorov-Smirnov Test

\begin{tabular}{|ll|r|}
\hline & & $\begin{array}{r}\text { Unstandard } \\
\text { ized } \\
\text { Residual }\end{array}$ \\
\hline$N$ & 70 \\
Normal & Mean & .0000000 \\
Parametersa & Std. Deviation & 42.40775771 \\
Most Extreme & Absolute & .116 \\
Differences & Positive & .097 \\
& Negative & -.116 \\
Kolmogorov-Smirnov Z & .968 \\
Asymp. Sig. (2-tailed) & .305 \\
\hline
\end{tabular}

a. Test distribution is Normal.

Sumber : Data diolah

Pada tabel 2 data menyebar disekotar garis diagonal, maka dapat dikatakan model memenuhi asumsi normalitas.Pada Grafik 4.2 nilai kolmograv adalah 0,968 pada signifikansi 0,305. Karena tingkat signifikansi diatas 0,05 yang artinya data terdistribusi normal.

\section{Uji Multikolinearitas}


Pengujian ada tidaknya gejala multikolinieritas dilakukan dengan memperhatikan nilai matriks korelasi yang dihasilkan pada saat pengolahan data serta nilai VIF (variance Inflation Factor) dan tolerance nya. Apabila nilai VIF berada dibawah 10 dan nilai tolerance tidak kurang dari 0.10 atau mendekati 1, maka diambil kesimpulan bahwa model regresi tersebut tidak terdapat problem multikolinieritas (Gozali, 2001). Hasil uji multikolinearitas indikator variabel independen dengan variabel dependen dapat dilihat dalam tabel 3 berikut ini:

Tabel 3

Hasil Uji Multikolinearitas Giro Wadi'ah, Tabungan Wadi'ah, Tabungan Mudharabah, dan Deposito Mudharabah Terhadap Laba

\begin{tabular}{|l|c|c|l|}
\hline \multicolumn{1}{|c|}{ Variabel } & $\begin{array}{c}\text { Toleran } \\
\text { ce }\end{array}$ & VIF & $\begin{array}{l}\text { Keterang } \\
\text { an }\end{array}$ \\
\hline Giro Wadi'ah & 0,683 & 1,464 & $\begin{array}{l}\text { Bebas } \\
\text { Multikol }\end{array}$ \\
\hline $\begin{array}{l}\text { Tabungan } \\
\text { Wadi'ah }\end{array}$ & 0,869 & 1,151 & $\begin{array}{l}\text { Bebas } \\
\text { Multikol }\end{array}$ \\
\hline $\begin{array}{l}\text { Tabungan } \\
\text { Mudharabah }\end{array}$ & 0,691 & 1,446 & $\begin{array}{l}\text { Bebas } \\
\text { Multikol }\end{array}$ \\
\hline $\begin{array}{l}\text { Deposito } \\
\text { Mudharabah }\end{array}$ & 0,689 & 1,452 & $\begin{array}{l}\text { Bebas } \\
\text { Multikol }\end{array}$ \\
\hline
\end{tabular}

Sumber : Data diolah

Hasil uji multikolinearitas pada tabel 4.3 diketahui bahwa semua variabel bebas mempunyai nilai tolerance lebih besar dari 0,10 dan nilai $V I F<10$. Hal ini dapat disimpulkan bahwa tidak terjadi multikolinearitas.

\section{Uji Heteroskedastisitas}

Ujigejala heterokedastisitas dapat diketahui dengan menggunakan scatter analysis. Jika titik-titik menyebar dan tidak membentuk pola yang khas maka uji regresi tidak terkena asumsi heteroskedastisitas. Hasil uji heterokedastisitas indikator variabel independen dengan variabel dependen dapat dilihat dalam gambar 4 sebagai berikut :

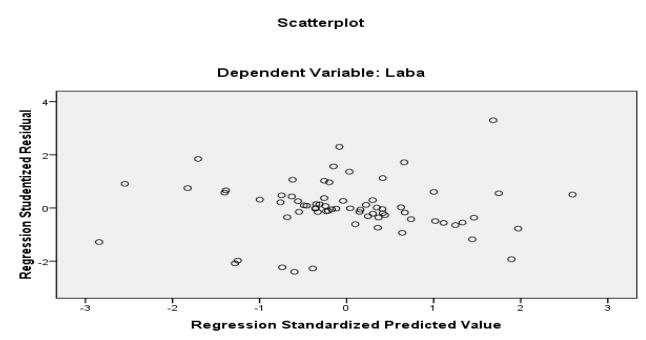

Sumber : Data diolah

Gambar 4

Hasil Uji Heteroskedastisitas Giro Wadi'ah, Tabungan Wadi'ah, Tabungan Mudharabah, dan Deposito Mudharabah Terhadap Laba

Pada Gambar 4menunjukkan bahwa titik-titik menyebar dan tidak membentuk pola yang khas. Dengan demikian dapat disimpulkan bahwa tidak terjadi gejala heteroskedastisitas pada model regresi. Dengan kata lain terjadi gejala homokedastisitas atau tidak terjadi hubungan antara variabel pengganggu dengan variabel bebas. (Sarjono, 2011:70)

\section{Uji Autokorelasi}

Uji ini digunakan untuk mengetahui ada tidaknya hubungan antar kesalahan pengamatan atau error residual. Untuk masalah autokorelasi pengujiannya dilakukan dengan melihat Durbin Watson-Watson Stat (DW). Jika nilai Durbin- Watson dalam output berada di antara nilai dU dan 4-dU, 
maka tidak terjadi autokorelasi.(Sarjono, $2011: 84)$. Hasil uji autokorelasi variabel independen dengan variabel dependen dapat dilihat dalam tabel 4 :

Tabel 4.

Hasil Uji Autokorelasi Giro Wadi'ah, Tabungan Wadi'ah, Tabungan Mudharabah, dan Deposito Mudharabah Terhadap Laba

\begin{tabular}{|c|c|c|c|c|}
\hline Variabel & $\mathrm{DU}$ & $4-d U$ & $\overline{D W}$ & Keterangan \\
\hline $\begin{array}{l}\text { Giro Wadiah, Tabungan } \\
\text { Wadi'ah,Tabungan } \\
\text { Mudharabah, dan Deposito } \\
\text { Mudharabah Terhadap } \\
\end{array}$ & 1,7351 & 2,2649 & 2,219 & \begin{tabular}{|l|} 
Bebas \\
Autokorelasi
\end{tabular} \\
\hline
\end{tabular}

Sumber : Data SPSS diolah

Tabel 4 menunjukkan bahwa pada model regresi tidak terjadi autokorelasi karena nilai Durbin Watson (DW) berada diantara nilai dU dan 4-dU.

\section{Analisis Regresi Linear Berganda dan Uji} Hipotesis

Tabel 5.

Pengaruh Giro Wadi'ah, Tabungan Wadi'ah, Tabungan Mudharabah, dan Deposito Mudharabah Terhadap Laba

\begin{tabular}{|l|c|c|c|}
\hline Variabel & $\begin{array}{c}\text { Koefisien } \\
\text { Regresi }\end{array}$ & $\mathrm{T}$ & Signifikansi \\
\hline (Constant) & 14,810 & 1,816 & 0,074 \\
\hline Giro Wadi'ah & $-0,657$ & $-1,428$ & 0,158 \\
\hline Tabungan Wadi'ah & 2,161 & 2,310 & 0,024 \\
\hline Tabungan Mudharabah & 2,390 & 1,060 & 0,293 \\
\hline Deposito Mudharabah & $-2,629$ & $-1,511$ & 0,136 \\
\hline Koefisien korelasi (R) & \multicolumn{3}{|c|}{0,372} \\
\hline Koefisien determinasi & 0,138 \\
\hline Uji F & 2,609 \\
\hline Signifikansi & 0,044 \\
\hline
\end{tabular}

Sumber : Data SPSS diolah

Dari tabel 5, model analisis yang pertama menunjukkan :

1. Hasil uji $F$ (simultan) menunjukkan bahwa pengaruh giro wadi'ah, tabungan wadi'ah, tabungan mudharabah, dan deposito mudharabah sebesar 2,609 dengan tingkat signifikansi 0,044 . Nilai signifikansi ini lebih kecil dari 0,05 sehingga dapat disimpulkan bahwa variabel giro wadi'ah, tabungan wadi'ah, tabungan mudharabah, dan deposito mudharabah secara bersama-sama berpengaruh signifikan terhadap laba perbankan.

2. Hasil pengujian parsial atau uji $\dagger$ pada tabel menunjukkan bahwa giro wadi'ah memiliki memiliki nilai signifikansi sebesar 0,158 , tabungan wadi'ah memiliki nilai signifikansi sebesar 0,024, tabungan mudharabah memiliki nilai signifikansi sebesar 0,293, dan deposito mudharabah memiliki nilai signifikansi sebesar 0,136.

Variabel yang memiliki nilai signifikansi t-statistik yang lebih kecil dari $5 \%$ adalah variabel tabungan wadi'ah. Sehingga dapat dikatakan variabel tabungan wadi'ah secara parsial memiliki pengaruh signifikam terhadap laba perbankan syariah.

Pembahasan Pengaruh Giro Wadi'ah, Tabungan Wadi'ah, Tabungan Mudharabah, dan Deposito Mudharabah Terhadap Laba Perbankan Syariah di Indonesia

1. Hasil penelitian menunjukkan bahwa Giro Wadi'ah memiliki pengaruh tidak signifikan terhadap laba yang dapat diidentifikasi dari taraf signifikansi Giro Wadi'ah yaitu 0,158 lebih besar dari 0,05. Jumlah komponen Giro Wadi'ah sangatlah 
kecil, terlihat pada hasil tabulasi data bahwa pertumbuhan Giro Wadi'ah berfluktuatif tetapi cenderung menurun. Hal ini dibuktikan dengan nilai minimum (penurunan pertumbuhan) hingga mencapai angka -29,47\% (Sumber: Lampiran Hasil Tabulasi Data dan Statistik Deskriotif Variabel Giro Wadi'ah). Kecilnya porsentase pertumbuhan Giro Wadi'ah, membuat variabel ini kurang bisa memberikan kontribusi besar terhadap pertumbuhan laba bersih perbankan syariah. Oleh karena iru, Giro Wadi'ah berpengaruh tidak signifikan.

2.Hasil penelitian menunjukkan bahwa Tabungan Wadi'ah memiliki pengaruh signifikan terhadap laba yang dapat diidentifikasi dari taraf signifikansi Tabungan Wadi'ah yaitu 0,024 lebih kecil dari 0,05 . Dari hasil tabulasi data dan dari hasil statistik deskriptif diketahui bahwasannya rata-rata pertumbuhan Tabungan Wadi'ah sebesar 3,8 ini paling besar dibandingkan rata-rata pertumbuhan ketiga variabel yang lain. Hal ini juga yang menyebabkan Giro Wadi'ah berpengaruh signifikan dikarenakan mampu menggenerate laba perbankan syariah. Selain itu, karakteristik dari tabungan itu sendiri yang sifatnya dapat ditarik sewaktu waktu, sehingga sumber dana bank syariah masih sangat didominasi oleh instrumen jangka pendek yaitu tabungan.( Laporan Perkembangan Kevangan Syariah 2013, 2013:5 diakses di www.ojk.go.id).

3. Hasil penelitian menunjukkan bahwa Tabungan Mudharabah dan Deposito Mudharabah memiliki pengaruh tidak signifikan terhadap laba yang dapat diidentifikasi dari taraf signifikansi Tabungan Mudharabah yaitu 0,293 lebih besar dari 0,05 dan Deposito Mudharabah yaitu 0,136 lebih besar dari 0,05. Tabungan Mudharabah dan Deposito Mudharabah merupakan Dana Syirkah Temporer (DST). Hak pihak ketiga atas bagi hasil dana syirkah temporer adalah bagian bagi hasil pemilik dana atas keuntungan dan kerugian hasil investasi bersama entitas syariah dalam suatu periode laporan keuangan. Hak pihak ketiga atas bagi hasil tidak dapat dikelompokkan sebagai beban (ketika untung) dan pendapatan (ketika rugi). Namun, hak pihak ketiga atas bagi hasil merupakan alokasi keuntungan dan kerugian kepada pemilik dana atas investasi yang dilakukan bersama dengan entitas syariah.(KDPPLKS Paragraf 107.Muthaher, 2012 :32-33). Dari penjelasan tersebut, dapat diketahui bahwasannya hak pihak ketiga atas bagi hasil tidak digolongkan sebagai beban ataupun pendapatan. Kita tahu bahwasannya laba bersih pada perbankan syariah diperoleh dari pengurangan antara pendapatan, beban, pajak, zakat. Sehingga sumber pendanaan perbankan syariah dengan 
prinsip mudharabah berpengaruh tetapi tidak signifikan terhadap laba.

4.Berdasarkan hasil pengujian secara simultan menunjukkan bahwa nilai $F$ sebesar 2,609 dengan tingkat signifikansi 0,044 dibawah 0,05 . Sehingga dapat disimpulkan bahwa secara simultan variabel giro wadi'ah, tabungan wadi'ah, tabungan mudharabah, dan deposito mudharabah berpengaruh signifikkan terhadap laba. Hal ini dikarenakan pertumbuhan setiap bank sangat dipengaruhi oleh perkembangan kemampuan menghimpun dana masyarakat (Muhammad, 2000 : 231). Tanpa dana yang cukup maka bank tidak dapat berfungsi sebagaimana mestinya.

\section{SIMPULAN}

Berdasarkan data dan hasil analisis yang telah dilakukan maka dapat diambil kesimpulan sebagai berikut :

1. Hasil dari uji simultan pada model regresi adalah variabel giro wadi'ah, tabungan wadi'ah, tabungan mudharabah, dan deposito mudharabah secara simultan berpengaruh signifikan terhadap laba bersih perbankan syariah.

2. Hasil uji parsial pada model regresi adalah variabel tabungan wadi'ah secara parsial berpengaruh signifikan terhadap variabel laba bersih perbankan syariah.

\section{DAFTAR PUSTAKA}

Anshori dan Iswati, 2009. Metodologi

Penelitian Kuantitatif. Surabaya:

Airlangga University Press

Arifin, Zainul. 2002. Dasar-Dasar Manajemen Bank Syariah. Jakarta: Alvabeta bekerjasama dengan Tazkia Institut

:PT. Syaamil Cipta Media

Bank Indonesia, 2013. Outlook Perbankan Syariah Tahun 2013. Jakarta, diakses di www.bi.go.id pada Tanggal 09 Oktober 2014

Departemen Agama RI. 2005. Al-Qur'an dan Terjemahannya. Bandung

Ekawati, Mardhiyyah Fitri. 2010. PenngaruhPembiayaan, Penempatan Dana Pada Bank Indonesia, Penempatan Dana Pada bank Lain, modal disetor dan Dana Pihak Ketiga Terhadap Laba Bank Umum Syariah dilndonesia.Skripsi tidak dipublikasikan.Surabaya : Fakultas Ekonomi dan Bisnis Universitas Airlangga

Ghazaly, Abdul Rahman, dk. 2010. Fiqh Muamalat. Jakarta : Kencana

Gozali, Imam. 2001. Aplikasi Analisis Multivariate dengan Program SPSS.Semarang: Fakultas Ekonomi Universitas Diponegoro Semarang. Ismail.2011. Perbankan Syariah. Jakarta : Kencana

.2010. Manajamen Perbankan

Dari Teori Menuju Aplikasi (Edisi

Pertama). Jakarta :Kencana 
2010.Akuntansi Bank Teori dan

Aplikasi Dalam Rupiah ( Edisi Pertama.

Jakarta :Kencana

Karim,Adiwarman.2006. Bank Islam :

Analisis Fiqih dan Keuangan. Jakarta:

PT RajaGrafindo

2010. Bank Islam : Analisis Fiqih

dan Keuangan (Edisi Keempat).

Jakarta : PT Raja Grafindo

Kasmir. 2012. Dasar-Dasar Perbankan. Jakarta: Rajawali Pers.

Kuncoro,Mudrajatdan Suhardjono, 2002. Manajemen Perbankan Teori dan Aplikasi. Yogyakarta :BPFE

Madura, Jeff. 2001. Pengantar Bisnis.

Terjemahan Jilid 2. Jakarta : Salemba

Empat

Mahaputra, Bob Fonda. 2008. Analisis

Pengaruh Dana Pihak Ketiga Terhadap

Laba Bersih Bank Pembiayaan Rakyat

Syariah Wilayah Kerja Surabaya.

Skripsi tidak

dipublikasikan.Surabaya: Fakultas

Ekonomi dan Bisnis Universitas

Airlangga

Mankiw, N.Gregory. 2003. Pengantar

Ekonomi Jilid I.Jakarta : Erlangga

Muhammad.2000.Analisis Kekuatan,

Pelvang, Kelemahan dan

Ancaman.Yogyakarta: Ekonisia 2004. Manajemen Dana Bank

Syariah. Yogyakarta : Ekonisia

.2005. Pengantar Akuntansi.

Jakarta : Salemba Empa

2011 . Manajamen Bank Syari'ah.

Yogyakarta : Unit Penerbit dan
Percetakan Sekolah Tinggi IImu

Manajemen YKPN

Nurdin, Upik Hamdani.2005. Analisis Penghimpunan Dana Plhak Ketiga dan

Pembiayaan Terhadap Pembentukan Laba Bersih Perbankan Syariah di Indonesia Periode Desember 2000-Juni $2005 . \quad$ Skripsi tidak dipublikasikan.Surabaya : Fakultas Ekonomi dan Bisnis Universitas Airlangga Otoritas jasa Keuangan, 2013. Laporan Perkembangan Keuangan Syariah 2013. Jakarta, diakses di www.ojk.go.id pada Tanggal 09 Januari 2014

Rosyidi, Suherman. 2003. Pengantar Teori Ekonomi Pendekatan Kepada Teori Ekonomi Mikro dan Makro. Jakarta: PT.Raja Grafindo

Samuelson, paul A dan Willuam D. Nordhaus. 1999. Mikroekonomi, Edisi

Ke-14. Jakarta: Erlangga

Sarjono, Haryadi dan Julianita, Winda. 2011. SPSS vS LISREL : Sebuah Pengantar, Aplikasi Untuk Riset. Jakarta : Salemba Empat

Syahatah, Husein.2001. Pokok-Pokok Pikiran Akuntansi Islam. Jakarta: Akbar Widarjono, Agus. 2010. Analisis Statistika Multivariat Terapan. Yogyakarta :UPP STIM YKPN

Yujana, Lalu Hendry. 1994. Akuntansi Keuangan Suatu Pengantar. Jakarta : $\quad$ FEUI 